\title{
Empirical Validation of Personal and Situational Traits in Usage of Transactional e-Government Services
}

\author{
Jongheon Kim
}

Auburn University

Montgomery, AL

United States

David Ang* corresponding author

Auburn University

Montgomery, AL,

United States

Email: dang@aum.edu

United States

Gang-hoon Kim

Electronics and Telecommunications Research Institute

Korea

Republic of Korea

\section{ABSTRACT}

With technology advanced and the flourishing of wired or wireless networks in our daily life, privacy and trustability of transaction media have become highly cherished value. Individuals often make choices in which they surrender a certain degree of privacy in exchange for outcomes or convenience that are perceived to be worthy of the risk of information disclosure. This research attempts to facilitate understandings of the utility of the Technology Acceptance Model (TAM) which is a strongly supported and well-established vehicle in information research and incorporates privacy, risk, and trust factor that are previously regarded as separate research areas from TAM. In addition, it also suggests individual dispositions as precursory factors and examines how they affect users' risk and trust perception in using transactional e-government services.

The proposed model was tested using data gathered from 309 respondents from an internet survey. Structural equation modeling (SEM) using Mplus was employed to validate measurement and structural model. Based on this outcome, the measurements were redefined as composite scores, and subsequent path analysis was conducted to test the proposed hypotheses. The findings provide the structural or causal model of the proposed model attainable, but it requires the development of reliable and valid measurement scales.

\section{Keywords: E-government services, Risk belief, Privacy concern, Trustability}

\section{Introduction}

The concept of e-government and electronic delivery of public services was initiated in the wake of the new wave of the 'information age' rhetoric unleashed by US vice president Al Gore in 1993. Since then, it has flourished that governmental services go online and enjoy benefits as private sectors capitalized on the e-commerce transformation.

E-government is conceptualized as intensive or generalized use of information technologies in governments for the provision of public services, the improvement of managerial effectiveness, and promotion of democratic values and mechanisms (Rose, Persson, et al. 2015) (Rose et. al., 2015). Another definition goes 'a delivery of government information and services online through the use of information and communication technologies (ICTs)' (Pantagiotopoulos, AlDehei, et al. 2012) (Pantagiotopoulos et. al., 2012). E-government makes it easier for citizens to become involved and contribute to government-related issues (Lips, Gil-Garcia et al. 2012) (Lips, Gil-Garcia, and Sorrentino, 2012). Brunschwig (2006) https://ijbassnet.com/ claims that e-government will improve the delivery of public services, such as online transactions and the dissemination of information about the operations carried out by government administrations. It is also predicted to improve the communication between citizens and the government, enabling more direct involvement from citizens in the governmental decision-making processes (Rana and Dwivedi 2015) (Rana and Dwivedi, 2015) through transparent, efficient, and effective delivery of various services to citizens (Carter et al., 2016; Reddic and Roy, 2013).

From the government perspective, information technologies provide two main opportunities: (1) to increase operational efficiency by reducing costs and increasing productivity and (2) to provide a better quality of services to its citizens. Meanwhile, with internet delivery systems citizens have unprecedented opportunities for more open access to government information and services. In turn, governments enhance responsiveness to citizens and increase public confidence by facilitating two-way interaction between citizens and http://dx.doi.org/10.33642/ijbass.v7n6p5 


\section{(C) Center for Promoting Education and Research (CPER) USA}

www.cpernet.org

bureaucrats (Gore 1993) (Gore, 1993). This interactive nature of electronic government fosters citizen participation in government decision-making and reshapes governance structures in the long run (Fountain 2001, Rodrigues, Sarabdeen, et al. 2016) (Rodrigues et al. 2016; Fountain, 2001).

Despite the promise of e-government as a potential source of new democracy and delivery of public services, there is a doubt cast on the utilization and capabilities of egovernment as a two-way communication tool. In 2018 UN eGovernment survey raised concerns about not only the digital divide, a disparity, of e-government adoption between developed countries and some developing regions in the globe but also escalated cybersecurity issues (2018). It also pointed out that most of the e-government services provided are still in the low-level state in e-government evolution (Al-Hujran, Aloudat et al. 2013, Rana and Dwivedi 2015) (Al-Hujran, Aloudat, and Altarawneh, 2013; Rana and Dwivedi, 2015), simple information services such as downloading a form and searching out policy information and regulations. Even though most U.S. government agencies have an online presence that provides quick access to their information and services, citizens are reluctant to transit into the online transactional stage (Ozkan and Kanat 2011, Pantagiotopoulos, Al-Dehei, et al. 2012) (Ozkan and Kanat, 2011; Panagiotopoulos et. al., 2015). (Wang2003)Wang (2003) also notes some transactional services are seriously underused despite their availability.

The adoption of information and communications technologies (ICTs) and related practices in the commercial sector, such as e-commerce, and the diffusion of the internet among the general public have resulted in a rising level of comfort and familiarity with the technologies in many contexts such as communication with people via instant messenger, electronic marketing, and academic activities through the electronic library. Such practices increase society's expectation that the public sector organizations will also provide services similar to those in the private sector with the same effectiveness and efficiency. Unfortunately, the adoption of egovernment services was significantly delayed in comparison to its commercial sector counterpart. Technology alone cannot ensure a full e-government adoption. The most significant obstacles for implementing e-government applications are computer security, privacy, and confidentiality of personal information (Gefen 2003, Lian 2015, Roy, Chartier, et al. 2015) (Gefen et al., 2002; Lian 2015; Roy et al., 2015). For example, one of the most sophisticated applications of egovernment is e-voting requires extensive security measures to ensure the due voting process and protect the voters' data.

This study, in an attempt to develop an integrative approach, casts the following research questions: (1) how do the individual citizens' concerns play preceding roles in the relationship of trust and perceived risk? (2) How do those two constructs interact with each other in the existence of TAM factors? (3) How do perceived risk and trust individually affect transactional e-government services? (4) Conversely, how will perceive ease of use (PEOU) and perceive usefulness (PU) interact with trust and perceived risk constructs and ultimately influence the intention of e-government adoption?

The paper is organized as follows: the next section reviews the relevant literature for constructs used in the proposed model and illustrates the differences in how they are defined, measured, and used in different contexts, and the research model will be introduced. Section three will discuss empirical outcomes from SEM analysis along with their statistical implications. The last section will summarize the theoretical basis of this research, provide theoretical implications of the research outcomes, and talk about some shortfalls of this research.

\section{Literature Review and Research Model}

Our theoretical model referred to as the e-Government adoption model is presented in Figure 1. The intention to transact with e-Government is proposed as the dependent variable. Based on findings from relevant prior research, the model integrates key factors such as perceived ease of use, perceived usefulness, trust beliefs, risk beliefs, and privacy concerns under the nomological structure of the theory of reasoned action (TRA) (Fishbein and I 1975, Ajzen and Fishbein 1980)(Fishbein and Ajzen, 1975; Ajzen and Fishbein, 1980; Ajzen, 1991). This section elaborates on the constructs in the model and the proposed relationships among them.

\section{Trust Beliefs in E-Government}

Trust can be generally defined as the degree to which one believes other parties will behave as expected in a socially responsible manner(Mayer, Davis, et al. 1995) (Mayer, Davis and Schoorman, 1995). Developing a sound trust relationship is important in many economic transactions where uncertainty is present. This is especially true in a variety of technologydriven environments such as e-commerce (Corbitt, Thanasankit, et al. 2003, Suh and Han 2003, Belanche, M Casalo, et al. 2014) (Belanche et al., 2014; Corbitt, Thanasankit and Yi, 2003; Suh and Han, 2003), m-commerce (Siau and Shen 2003, Siau, Sheng, et al. 2004) (Siau and Shen, 2003; Siau, Sheng, Nah and Davis, 2004), and t-commerce (Yu, Ha et al. 2005)(Yu, Ha, Choi and Rho, 2005). In the field of e-commerce, trust has been extensively researched in a variety of ways (Salam, Lakshmi, et al. 2005, Chen, Jubilado, et al. 2015) (Chen et al. 2015; Salam, Lakshmi, Palvia and Singh, 2005). Recognizing previous studies are divergent in how they conceptualize trust, Gefen, Rao, and Tractinsky (2003) maintain that trust in the context of B2C commerce can be defined as (1) a general belief in a Web retailer that leads to behavioral intention, (2) as a combination of trustworthiness, integrity, and benevolence of Web retailers that increases behavioral intentions through reduced risk among potential but inexperienced consumers, (3) as beliefs in integrity, benevolence, and ability that result in a general belief in trust, or (4) as specific beliefs in competence, 
integrity, and benevolence that result in trusting intentions. as one of the important factors that influence intention to Although slightly different in their conceptualization of trust, engage in e-commerce transactions and thus facilitate the these studies identify building consumer trust in Web retailers continued growth of B2C commerce.

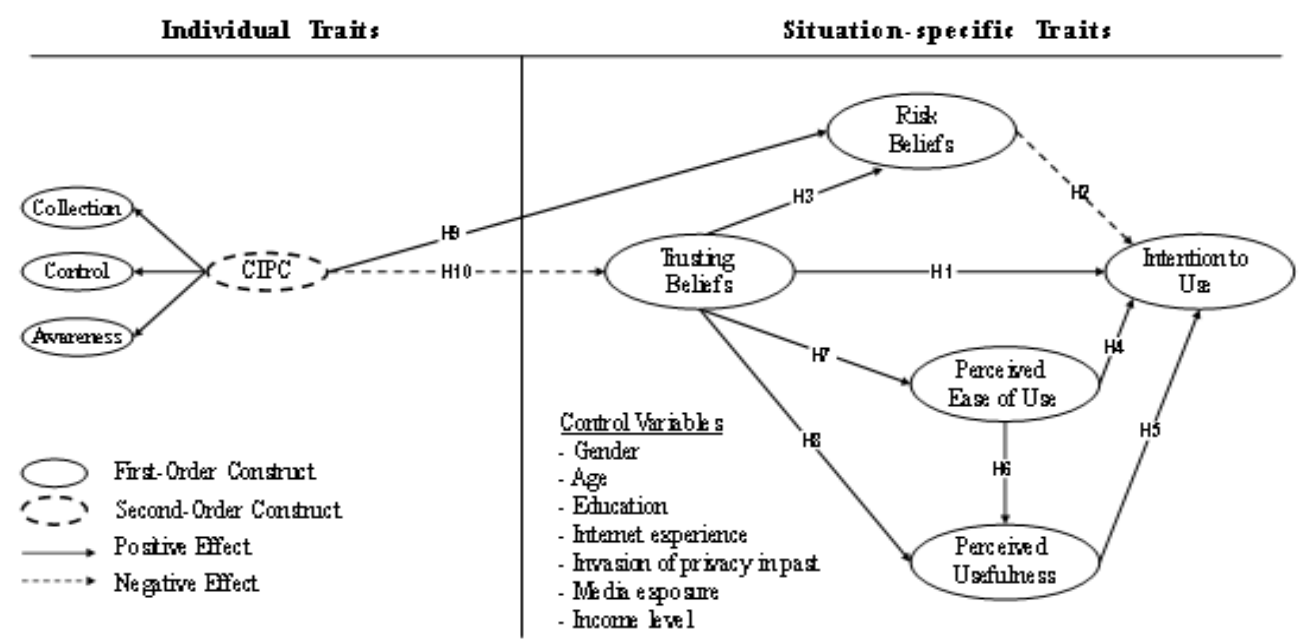

Figure 1. E-Government Adoption Model

E-government is also characterized by the lack of a consumer trust in the infrastructure through a variety of physical presence and its uncertain environment (Warkentin, $\mathrm{G}$ et al. 2002) (Warkentin et al., 2002). Presumably, this impersonal nature may lead citizens to develop low confidence in online transactional services that require sensitive personal information. Indeed, those services might face more scrutiny from citizens than Web tailors do. Therefore, it is essential to develop citizen trust in e-Government for the continued growth of e-government (Pavlou 2003, Belanger and Carter 2008, Xie, Song, et al. 2017) (Belanger and Carter, 2008; Pavlou, 2003; Xie et al., 2017). Among the four perspectives above, this study adopts the view that conceptualizes trust as a set of specific beliefs (McKnight, Choudhury, et al. 2002) (McKnight, Choudhury and Kacmar, 2002).

We define trust beliefs in e-government as a set of salient beliefs that allow citizens to willingly rely on eGovernment and provide sensitive personal information in situations where such actions make the citizen vulnerable to eGovernment (Warkentin, G et al. 2002) (Warkentin et al., 2002). This definition includes the most widely used specific beliefs benevolence, integrity, honesty, reliability, and predictability (Gefen 2003) (Gefen et al., 2002). As Pavlou (2003) points out, these salient beliefs may include not only trust in a specific party (i.e. online store) but also trust in the integrity of the transaction medium (i.e. Internet, interface). In the context of e-Government, Carter and Belanger (2005) argue that situational normality (trust of the Internet) is positively related to citizens' intentions to use online transactional services.

However, the role of trust in the infrastructure is excluded from our definition because ample e-commerce literature shows that Web tailors can significantly influence behavioral actions that intend to reduce consumer concerns associated with the uncertain online environment and increase consumer trust in e-commerce (e.g., online privacy seal program: Benassi, 1999; Lou, 2002). This view is also shared by Pavlou (2003), who argued that trust in Web tailors embraces a considerable portion of trust in the focal transaction even though they have limited control over the Internet. In addition, because trust is often identified as a single construct in the egovernment adoption context (Lian, 2015), as the major target of trust, therefore, we focus on e-Government, rather than the related technological infrastructure. Consistent with previous studies in the context of B2C commerce (Jarvenpaa and Tractinsky 1999, Gefen 2003) (Jarvenpaa and Tractinsky, 1999, Gefen et al., 2002), our definition views trust as a rationale choice process that excludes affective dimensions and thus do not include those dimensions such as friendship or love.

Lastly, our definition builds on TRA and thus views trust as a set of specific beliefs that are separated from actual behavioral intention. This distinction is consistent with other studies that made a clear distinction between a trust and actual behavioral intentions in ongoing economic relationships (Jarvenpaa, Tractinsky, et al. 2000, Gefen 2003, Pavlou 2003) (Jarvenpaa, Tractinsky, and Vitale, 2000; Gefen et al., 2003; Pavlou, 2003). Based upon TRA, these previous studies show that heightened levels of trust are positively related to heightened levels of intended use in the context of B2C commerce. Arguably, the same result is expected in the context of eGovernment.

H1: Citizen's intentions to transact online with e-Government are positively related to trust beliefs in e-Government. 


\section{Risk and Trust Beliefs in E-Government}

When engaging in an online transaction process that requires sensitive personal information, a consumer tends to be uncertain about the risks at present and their effects (Pavlou 2003, Lian 2015, Roy, Chartier, et al. 2015) (Lian, 2015; Pavlou, 2003; Roy et al., 2015). In the context of inter-organizational relationships, risk beliefs have been conceptualized to encompass two forms of uncertainty including behavioral uncertainty (the trading partner) and environmental uncertainty (the infrastructure) (Ring and Van de Ven 1994, Bensaou and Venkatraman 1996) (Ring and Van de Ven, 1994; Bensaou and Venkatraman, 1996). However, in the context of B2C commerce, consumers tend to develop their subjective expectations of the Web tailor during online transaction processes, making it difficult to capture risk itself as an objective reality (Pavlou, 2003). As a result, these two forms of uncertainty have been viewed collectively as a higher-order unidimensional construct (Jarvenpaa and Tractinsky 1999, Jarvenpaa, Tractinsky, et al. 2000) (Jarvenpaa and Tractinsky, 1999; Jarvenpaa et al., 2000). Following this notion, this study defines risk beliefs as the degree to which a citizen subjectively assesses the uncertainty and adverse consequences of engaging in e-Government transactional services (Warkentin, G et al. 2002) (Warkentin et al., 2002). Risk beliefs, as a set of salient beliefs, are expected to lower citizens' intention to use online transactional services. Because high levels of risk beliefs represent a lack of behavioral control, this argument can be explained by TRA, which indicates that the perceived behavioral control influences IT use intentions (Taylor and Todd, 1995).

H2: Citizen intentions to transact with e-Government are negatively related to risk beliefs in e-Government.

Trust and risk are closely interrelated because trust plays an important role in attenuating one's risk beliefs (Mayer, Davis, et al. 1995, Lou 2002, Sirdeshmukh, Singh, et al. 2002) (Mayer et al., 1995; Lou, 2002; Sirdeshmukh, Singh and Sabol, 2002). In the B2C e-commerce context, trust helps reduce the uncertainty a consumer's faces and thus can be considered as a mechanism that mitigates the consumer's risk beliefs during an online transaction (Jarvenpaa and Tractinsky 1999, Jarvenpaa, Tractinsky, et al. 2000, Malhotra, Kim, et al. 2004) (Jarvenpaa and Tractinsky, 1999; Jarvenpaa et al., 2000; Pavlou, 2003; Malhotra, Kim and Agarwal, 2004). Extrapolating from these findings to the context of eGovernment, we propose that trust beliefs in e-Government could be depicted as a function of the levels of risk beliefs in eGovernment.

H3: Risk beliefs in e-Government are negatively related to trust beliefs in Government.

Technology Acceptance Model and Intention to Transact with E-Government

In essence, the Technology Acceptance Model proposes that perceived ease of use and perceived usefulness are salient behavioral beliefs that determine consumer intentions to use information technologies (Davis 1989) (Davis, 1998). TAM has been widely used to describe and predict the use of a variety of new information technologies (Venkatesh and Davis 2000) (Venkatesh and Davis, 2000) including Internet-based technologies (Wang and Benbasat 2005) (e.g., online recommendation agents: Wang and Benbasat, 2005). Unlike trust beliefs and risk beliefs, perceived ease of use and perceived usefulness have drawn considerable attention among researchers who examined the adoption of eGovernment transactional services (Warkentin, G et al. 2002, Wang 2003, Gilbert and Balestrini 2004, Carter and Belanger 2005) (Wang, 2003; Warkentin et al., 2002; Gilbert and Balestrini, 2004; Carter and Belanger, 2005). Using TAM as a basic framework, these studies show the applicability of TAM in understanding citizen perception of e-Government services. A recent survey (Hart-Teeter 2003) (Hart-Teeter, 2003) also indicates that citizens value ease and efficiency as the potential benefits of e-Government, further suggesting that corresponding TAM variables could be useful in the eGovernment context.

Following previous work (Davis 1989, Warkentin, G et al. 2002, Xie, Song, et al. 2017) (Davis, 1989; Warkentin et al., 2002; Xie, 2017), we define perceived usefulness as the degree to which a citizen subjectively assesses the utility of eGovernment transactional services. Perceived ease of use refers to the degree to which a citizen believes that utilizing those services will be effortless. There is a broad agreement that each construct has a positive relationship with intentions to use Internet-based systems (Lederer, Maupin et al. 1999, Moon and Kim 2001) (Lederer et al., 1999; Moon and Kim, 2001) including online tax filing systems (Wang 2003). In addition, these studies show that perceived ease of use influences intentions indirectly through perceived usefulness. Therefore, we hypothesize that all three paths previously validated in many studies apply to e-Government.

H4: Citizens' intention to transact with e-Government is positively related to the perceived ease of use of $e$ Government.

H5: Citizens' intention to transact with e-Government is positively related to the perceived usefulness of e-Government. H6: The perceived usefulness of e-Government is positively related to the perceived ease of use of e-Government.

\section{Nature of The Relationships Between TAM and Trust}

As discussed previously, a large body of the literature provides sound theoretical and empirical supports for identifying factors that influence usage intentions of a variety of information technologies. In the $\mathrm{B} 2 \mathrm{C}$ commerce context, both trust and two constructs from TAM have been widely suggested as the most crucial determinants that explain a significant part of usage intention (Salam, Lakshmi, et al. 2005, Belanche, M Casalo, et al. 2014) (Belanche et al., 2014; Salam et al., 2005). In addition, there is a great deal of literature 
(Chircu, Davis, et al. 2000, D and Straub 2003, Gefen 2003, Pavlou 2003) (Chircu et al., 2000; Gefen et al., 2003; Gefen and Straub, 2003; Pavlou, 2003) that investigated the relationships among three constructs. Ring and Van de Ven (1994) suggest that trust helps lower a sense of the costs (time and effort) that each party will face. In a trusting relationship where monitoring or legal guarantees are impractical, people willingly depend on the other party and take action. Otherwise, a consumer should devote previous resources to monitoring and controlling the situation. This makes the transaction much difficult for the consumer. In the context of B2C commerce, trust positively influences perceived ease of use by decreasing the need for a buyer to invest time and effort to identify all aspects of a seller (Chircu, Davis, et al. 2000, Pavlou 2003) (Chircu et al., 2000; Pavlou, 2003). Applied to the eGovernment context, this notion supports the following hypothesis.

H7: Trust beliefs in e-Government are positively related to the perceived ease of use of e-Government.

Research following social exchange theory (Thibault and Kelley, 1959) shows that trust increases perceived usefulness in an online environment (Gefen and Keil 1998, Gefen 2003) (Gefen and Keil 1998; Gefen et al., 2003). The central theme of social exchange theory is that when there is social uncertainty as to how others will behave, trust determines people's expectations from the relationship - the nature of the utility expected (Konovsky and Pugh 1994, Fukuyama 1995, Chircu, Davis, et al. 2000) (Konovsky and Pugh, 1994; Fukuyama, 1995). Chircu et al. (2000) argued that trust positively affects perceived usefulness because trust allows consumers to depend on the Web tailor and gives an assurance that they can gain any utility from the transaction. Pavlou (2003) also shares this view, maintaining that trust forms a significant part of the guarantee that consumers will gain their expected usefulness from the Web tailor. Applied to the e-Government context, trust is viewed as a measure that increases citizen's subjective beliefs that e-Government will provide what has been expected in a socially responsible manner (Warkentin, G et al. 2002) (Warkentin et al., 2002). In this way, the trust allows citizens to expect that they gain benefits from using online transactional services.

H8: Trust beliefs in e-Government are positively related to the perceived usefulness of e-Government.

Citizens' Information Privacy Concerns as Antecedents of Trust and Risk Beliefs

As discussed previously, there are significant challenges to the further growth of e-Government from information dissemination to transactions. Despite their availability, online transactional services appear to be underutilized. However, this does not mean citizens are not interested in using e-government for transactions. A series of recent surveys indicate that this low acceptance of transactional services is primarily due to the public's privacy concerns. The Hart-Teeter national survey reported by GAO (2001) found that although U.S. citizens believe e-government services are beneficial, they are reluctant to provide personal information with the government over the Internet. A survey conducted by Hart-Teeter for the Council for Excellence in Government (2003) also reveals that the use of e-government for online transactions is still uncommon even though half of the users $(65 \%)$ expressed strong interest in transactional services. In a recent survey by the Gallup Organization, most respondents $(85 \%)$ listed online privacy as their top issue. Moreover, this issue is stifling the growth of e-government around the world. According to a report from Taylor Nelson Sofres (2002) that examined e-government in 27 countries and surveyed more than 29,000 people, only one-tenth $(7 \%)$ of users engaged in transactional services that request personal or household information. A survey was done by Accenture (2004) that investigated e-government in 22 countries also identifies the lack of citizen confidence in online privacy as one of the main barriers hampering the development of egovernment around the world. There is ample evidence that citizens' concerns of information privacy should be viewed as one of the crucial factors that influence the acceptance behavior of online transactional services (Casalo, Flavian, et al. 2007, Chiu, Chang, et al. 2009, Bansal, Zahedi, et al. 2010) (Bansal, Zahedi, and Gefen, 2010; Casalo, Flavian and Guinaliu, 2007; Chiu, Chang, Cheng and Fang, 2009). However, previous research on citizen adoption of e-Government has yet to identify privacy concerns as a major factor. Therefore, to better highlight the citizen acceptance phenomenon, our theoretical model includes this construct the inherent privacy concerns that arise with the use of online transactional services.

Indeed, the issue of information privacy is not new. Westin (1967, p.7) defines information privacy as "the claim of individuals, groups, or institutions to determine for themselves when, how, and to what extent information about them is communicated with others." Since companies have begun to collect customer information, the issue has drawn considerable attention among scholars (Culnan 1993, Milberg, Burke et al. 1996, Henderson and Snyder 1999) (Milberg, Burke, Smith, and Kallman, 1995; Culnan, 1993; Henderson and Snyder, 1999) and practitioners (Stepanek 1999, Green 2001) (Stepanek, 1999; Green, 2001). Furthermore, with the rapid advance in new information technologies, companies now efficiently collect, store, use, and communicate consumer information for various marketing purposes (Glazer 1991, Campbell 1999) (Campbell, 1999;

Glazer, 1991). However, this practice has led consumers to be more concerned about their privacy and to react by being unwilling to provide their information (Hagel III and Rayport 1997, Olivero and Lunt 2004, Culnan and Williams 2009) (Culnan and Williams, 2009; Hagel and Rayport, 1997; Olivero and Lunt, 2004). 
Several studies (Milberg, Burke et al. 1996, Stewart and Segars 2002, Liu, Marchewka, et al. 2004, Malhotra, Kim et al. 2004, Smith, Dinev, et al. 2011) (Smith, Dinev and Xu, 2011; Smith, Milberg and Burke, 1996; Stewart and Segars, 2002; Liu, Marchewka, Lu and Yu, 2004; Malhotra, 2004) have attempted to conceptualize and measure such concerns. For this study, we adopt Malhotra et al.'s Internet Users' Information Privacy Concerns (IUIPC), designed to measure Internet users' concerns about information privacy. Based on social contract theory that is rooted in the principle of procedural justice (Gililand, 1993), the scale takes into account recent changes in an individual's views on fairness because of the common use of the Internet (Malhotra, 2004). Thus, it provides both a practical and theoretical foundation for the better conceptualization of privacy concerns within the context of an online environment. Extending their work, we define Citizens' Information Privacy Concerns (CIPC) as the degree to which a citizen subjectively views fairness/justice of eGovernment transactional services and conceptualize CIPC as a second-order factor that consists of three first-order factors including collection (whether the exchange of personal information is equitable), control (whether I have control over the data) and awareness (whether I am adequately informed about the use of the data). Because people have different views of fairness/justice regarding e-Government's use of their personal information, CIPC is viewed as a personal trait.

In addition, this study focuses on inexperienced citizens with online transactional services. With these distinctions in mind, to identify relationships between CIPC and other constructs, we rely on personality-based trust research stream, which suggests that personal dispositions play important role in creating initial trust beliefs and risk beliefs (Mayer, Davis, et al. 1995, McKnight, Cummings, et al. 1998, McKnight, Choudhury, et al. 2002) (Mayer et al., 1995; McKnight, Cummings and Chervany, 1998; McKnight, Choudhury and Kacmar, 2002). In the context of B2C commerce, individual traits also strongly influence initial trust formation (Reichheld and Schefter, 2000). Although conceptualizing privacy concerns differently, Liu et al. (2004) suggested that privacy acts as the major antecedent of trust, which in turn influences the behavioral intentions. Malhotra et al. (2004) empirically showed that IUIPC has significant relationships with both trusting beliefs and risk beliefs, indicating that users who tend to worry over their information privacy are likely to be low on trust beliefs and high on risk beliefs. Following Malhotra et al., this study proposes that CICP, as an individual trait, influences trusting beliefs negatively and risk beliefs positively (see Figure 1). In this way, CIPC is posited under the nomological structure of TRA, which suggests that the impact of personal dispositions (CIPC) on behavioral intention is fully mediated by salient beliefs (trusting beliefs and risk beliefs).

H9: Citizens' information privacy concerns are positively related to risk beliefs in e-Government.

H10: Citizens' information privacy concerns are negatively related to trusting beliefs in e-Government.

\section{Research Methodology}

\section{Scale Development and Survey Administration}

The present research model was empirically tested by using data collected through an Internet survey. We adopted the research frameworks by Malhotra et. al. (2004) and Davis (1986) to construct the initial set of items by reflecting on the proposed theoretical model. Collection, Awareness, and Control items were based on the instruments developed by Malhortra et. al. and refined further to fit our research context. Risk Belief and Trust Belief constructs were measured by 5 items each based on Pavlou (2003). The two items for independent constructs of TAM, that is Perceived Ease of Use and Perceived Usefulness, were developed by Venkatesh and Davis (2000), and Pavlou (2003). Finally, the behavioral intention was measured by 6 items that are based on willingness to provide private information for Internet transactions by Dinev and Hart's (2006).

All the instrument items used a seven-point Likert scale and the survey was administered to a random sample of individuals in Korea through Internet. Participation was voluntary and the respondents who chose to participate were asked to visit a relevant g-government website to quantify participant's perceptual easiness and usefulness about egovernment services. The survey respondent profile (sample size 309) is given in Table 1.

\begin{tabular}{|c|c|c|c|}
\hline Gender & & Age & \\
\hline Male & $143(46.3 \%)$ & $<25$ years & $114(36.9 \%)$ \\
\hline Female & $165(53.4 \%)$ & $25-34$ years & $137(44.3 \%)$ \\
\hline & & $\begin{array}{l}35-44 \text { years } \\
45-54 \text { years } \\
55-65 \text { years } \\
>60 \text { years }\end{array}$ & $\begin{array}{l}48(15.5 \%) \\
8(2.6 \%) \\
1(0.3 \%) \\
0\end{array}$ \\
\hline Education & & Income & \\
\hline some school, no & $5(1.6 \%)$ & $<S 10000$ & $161(52.1 \%)$ \\
\hline $\begin{array}{l}\text { high school } \\
\text { graduate }\end{array}$ & $25(8.1 \%)$ & $\$ 10000-\$ 20000$ & $41(13.3 \%)$ \\
\hline $\begin{array}{l}\text { some college, no } \\
\text { degree }\end{array}$ & $131(42.4 \%)$ & $\$ 20000-\$ 30000$ & $53(17.2 \%)$ \\
\hline bachelor's degree & $85(27.5 \%)$ & $\$ 30000-\$ 40000$ & $19(6.1 \%)$ \\
\hline $\begin{array}{l}\text { master's degree } \\
\text { doctorate degree }\end{array}$ & $\begin{array}{l}46(14.9 \%) \\
15(4.9 \%)\end{array}$ & $\begin{array}{l}\$ 40000-\$ 50000 \\
\$ 50000-\$ 60000\end{array}$ & $\begin{array}{l}9(2.9 \%) \\
7(2.3 \%)\end{array}$ \\
\hline & & $>\$ 60000$ & $17(5.5 \%)$ \\
\hline
\end{tabular}

Table 1. Descriptive Statistics of Respondents $(N=309$, missing $=1)$ 


\section{Structural Equation Modeling-Measurement Model}

Anderson and Gerbing (1988) suggest that to avoid misinterpretation of structural relationships, researchers should first estimate a measurement model before testing hypotheses. The present research adopted this two-step approach in which first a valid and reliable measurement was established, and then the structural model of Figure 1 was tested. As the first step, we conducted a confirmatory factor analysis (CFA) on the data collected from the Internet survey to examine the measurement model. Since the sample size usually tends to overestimate the exact-fit index, chi-square, we mostly relied on close-fit indices. In particular, model fit was assessed in terms of three indices: comparative fit index (CFI), root mean square error of approximation (RMSEA), and standardized root mean square residual (SRMR). The recommended cut-off criteria for those indices are CFI $>0.95$, RMSEA $<0.06$, and SRMR $<0.08$ (Hu and Bentler 1999).

The result of CFA indicated that the initial measurement model did not fit the data well $[\chi 2(495)=$ 1703.031, CFI $=0.812$, RMSEA $=0.089, \mathrm{SRM}=0.096]$. After inspecting the modification index provided by Mplus output, we refined measurement items by rearranging them to other latent constructs and establishing a correlation among indicators as suggested. Specifically, we reassign Risk Belief (RB) item number 5 to one of the Trust Belief (TB) indicators, Perceived Usefulness (PU) item number 4 to Perceived Easiness (PE), and Control item number 3 to Collection construct. We also allowed PU1 and PU2, TB1 and TB2, and RB3 and RB4 to correlate with each other. The modified model, however, did not show drastic improvement in model fit $[\chi 2(493)=1375.051, \mathrm{CFI}=0.863$, RMSEA $=0.076$, SRMR $=0.075]$ and yet it fitted poorly the data even though the more constraint model, the later revealed significantly better fit than the parsimonious model $(\Delta \chi(2)<0.0000)$.

\section{Structural Equation Modeling-Structural Model}

Since the measurement model failed to provide concrete measurement background, we decided not to test hypotheses using the structural model where all latent constructs are indicated by manifest variables. Rather, we chose to test the hypotheses and causal relationships using composite scores of indicators by averaging them and treat previously latent variables as manifest variables.

To make a sounder analysis, we decided to abandon all instrument scaling that we relied on for the measurement model. Rather we performed exploratory factor analysis (EFA) to redefine and scale measures in a different way. Factor analysis with Oblimin rotation was performed through SPSS Principal Axis factoring all 34 items from 8 different constructs. Seven factors having greater than eigenvalue of 1 were identified and extracted.

Loadings of variables on factors, communalities, and percent of variance and covariance are shown in Table 2 . According to the result, we can interpret Control and Awareness are not two distinct constructs that were previously considered as different constructs. In addition, some items from Perceived Usefulness (item 3 and 4) loaded on Perceived Easiness construct and one of Risk Belief (item 5) belonged to Trust Belief.

Before we conducted path, analysis using a new measurement scale, we also examined the reliability of the measurement. All seven measures indicated Cronbach's alpha greater than 0.822 .

Subsequently, we further carried out the path analysis with the proposed causal relationship model. The result was satisfactory as it was initially expected. Fit indices showed significant improvement $[\chi 2(7)=19.239, \mathrm{CFI}=0.968$, RMSEA $=0.075, \mathrm{SRMR}=0.044]$.

Table 2. Factor Loading

\begin{tabular}{|c|c|c|c|c|c|c|c|}
\hline & \multicolumn{7}{|c|}{ Factor } \\
\hline & 1 & 2 & 3 & 4 & 5 & 6 & 7 \\
\hline pu3 & .512 & .153 & .068 & .025 & -.128 & -.022 & -.232 \\
\hline pu4 & .609 & -.012 & .043 & .010 & .026 & .016 & -.358 \\
\hline pe1 & .836 & .034 & .008 & .022 & -.006 & .017 & -.057 \\
\hline pe2 & .748 & .014 & .010 & -.073 & -.026 & .044 & .187 \\
\hline pe3 & .829 & -.038 & -.026 & -.071 & -.027 & -.062 & -.042 \\
\hline pe4 & .727 & -.088 & .061 & .025 & .085 & -.008 & .004 \\
\hline collection1 & .024 & -.618 & .002 & -.010 & -.328 & .087 & .067 \\
\hline collection2 & .054 & -.664 & -.027 & -.010 & -.196 & .133 & .010 \\
\hline collection3 & -.010 & -.742 & .016 & -.010 & -.009 & .306 & -.039 \\
\hline collection4 & .001 & -.671 & -.050 & .033 & -.074 & .330 & -.051 \\
\hline Trustbelief1 & -.050 & -.025 & .765 & -.036 & -.130 & -.030 & .037 \\
\hline Trustbelief2 & -.029 & -.034 & .844 & .026 & .003 & -.030 & -.054 \\
\hline Trustbelief3 & .078 & -.077 & .778 & .028 & .159 & .008 & .016 \\
\hline Trustbelief4 & .162 & .067 & .578 & -.020 & -.097 & .073 & .147 \\
\hline
\end{tabular}




\section{(C) Center for Promoting Education and Research (CPER) USA}

wwW.cpernet.org

\begin{tabular}{llllllll} 
Trustbelief5 & .017 & -.036 & .771 & -.030 & .047 & -.017 & -.084 \\
RiskBelief5 & -.064 & .095 & .581 & -.067 & .030 & -.073 & -.166 \\
Intention1 & .134 & -.276 & -.028 & -.672 & -.084 & -.168 & -.046 \\
Intention2 & .039 & -.238 & .002 & -.731 & .019 & -.059 & -.100 \\
Intention3 & -.034 & .022 & .052 & -.693 & -.031 & .066 & .009 \\
Intention4 & -.040 & .337 & .168 & -.601 & -.015 & .096 & -.022 \\
Intention5 & .046 & .252 & .106 & -.672 & .022 & .082 & .003 \\
Intention6 & .192 & .108 & -.104 & -.487 & -.019 & .044 & -.374 \\
control1 & .012 & .149 & -.014 & .012 & -.770 & .097 & .008 \\
control2 & .039 & .064 & -.011 & .099 & -.680 & .138 & -.111 \\
control3 & .048 & -.237 & .096 & .026 & -.505 & .143 & .058 \\
aware1 & -.042 & -.022 & -.039 & -.042 & -.730 & .008 & -.004 \\
aware2 & .069 & -.046 & -.005 & -.115 & -.679 & -.029 & .029 \\
aware3 & -.050 & -.167 & .027 & -.011 & -.717 & -.113 & -.022 \\
RiskBelief1 & .063 & -.187 & -.024 & .070 & -.077 & .465 & -.101 \\
RiskBelief2 & .044 & -.246 & -.025 & .067 & .057 & .602 & -.106 \\
RiskBelief3 & -.038 & .006 & -.050 & -.081 & -.058 & .812 & .026 \\
RiskBelief4 & -.019 & .018 & -.002 & -.043 & -.080 & .808 & .041 \\
pu1 & .050 & .027 & .103 & -.083 & -.067 & .051 & -.793 \\
pu2 & .048 & -.057 & .051 & -.080 & -.011 & .028 & -.870 \\
\hline Exy
\end{tabular}

Extraction Method: Principal Axis Factoring.

Rotation Method: Oblimin with Kaiser Normalization.

a Rotation converged in 14 iterations.

\section{Testing Hypotheses and Discussion}

The present research adopted two distinctive information systems models that are assessing end-user's behavioral intention and combined them to develop a more integrated model by taking into account current individual's privacy concerns. Even though all measurement scales were adopted from prior literature, CFA did not turn out the desirable outcome of model fit.

As an alternative approach, we carried out path analysis using a composite score of latent constructs. Contrarily to the measurement model and the subsequent structural model, the result of the analysis indicated the path model was well suited to the collected data. Hence, we were
Table 3. Path Model Results

able to conduct hypothesis testing as the next step. The result revealed that all hypotheses except $\mathrm{H} 2$ and $\mathrm{H} 3$ were supported. Table 3 summarizes the path loadings of the hypothesized path model.

Successful verification of the path model suggested a possible remedy for the structural model with latent constructs. From this result, we were aware most causal relationships between constructs valid rather a big problem lies in the measurement portion of the model. As examined already, problems in measurement may be stemmed from intermingles of numerous indicators representing each latent construct, which is most likely to lead to multicollinearity problems among indicators.

\begin{tabular}{|c|c|c|c|c|c|}
\hline$D V$ & & IV & Estimate & $S . E$ & $t$-score \\
\hline \multirow[t]{3}{*}{ ТВ } & on & & & & \\
\hline & & Control & 0.170 & 0.078 & 2.168 \\
\hline & & Collection & -0.164 & 0.053 & -3.115 \\
\hline \multirow[t]{4}{*}{$\mathrm{RB}$} & on & & & & \\
\hline & & Control & 0.249 & 0.066 & 3.787 \\
\hline & & Collection & 0.383 & 0.045 & 8.591 \\
\hline & & TB & -0.054 & 0.048 & -1.130 \\
\hline \multirow[t]{2}{*}{ PE } & on & & & & \\
\hline & & TB & 0.271 & 0.044 & 6.200 \\
\hline \multirow[t]{3}{*}{ PU } & on & & & & \\
\hline & & PE & 0.639 & 0.074 & 8.628 \\
\hline & & TB & 0.149 & 0.061 & 2.428 \\
\hline \multirow[t]{5}{*}{ INT } & on & & & & \\
\hline & & $\mathrm{RB}$ & -.039 & 0.049 & -0.789 \\
\hline & & TB & 0.249 & 0.054 & 4.593 \\
\hline & & PE & 0.173 & 0.072 & 2.388 \\
\hline & & PU & 0.250 & 0.050 & 5.026 \\
\hline
\end{tabular}




\section{(C) Center for Promoting Education and Research (CPER) USA}

wwW.cpernet.org

Another possible cause of measurement problems is violations of multivariate normality and linearity of indicators. To assess the problem, we construct a histogram for visual inspection of normality using SPSS, most of the indicators were seriously skewed and were out of bell-shaped. Even though the survey instrument was adapted from wellestablished measuring scales, there may be some flaws involved while it was converted into the present research context or translated into the Korean language.

\section{Conclusion}

This research examines the role of trust belief and perceived risk in conjunction with the traditional technology acceptance theory in predicting citizen's usage intention of transactional e-government services. Personal disposition is also included as an antecedent of trust belief and perceived risk. Three different traits constitute an individual's privacy concern. They are the collection of private information, awareness of the information use, and control over own private information.

The results reveal that both trust belief and perceived risk affect citizens' intention to use transactional e-government services, but trust belief has a direct effect on the intention whereas perceived risk indirectly affects the intention construct. In addition, an individual's privacy concern was initially thought to have antecedent effects both on trust belief and perceived risk by $\mathrm{H} 9$ and $\mathrm{H} 10$, but it has an only valid preceding effect on perceived risk (H9) rather than trust. The complete results of all hypothesis tests are provided in Table 4.

From a theoretical perspective, the contributions of this study are three-fold. First of all, this research is one of the attempts to integrate the trust-risk aspects in the presence of
TAM in predicting usage intention of transactional egovernment services. Previous researches usually rely on one of the focal aspects, either taking a view from acceptance of various information technologies (Taylor and Todd 1995, Szajna 1996, Gefen and Straub 1997, Venkatesh and Davis 2000) (Gefen and Straub, 1997; Jackson, chow and Leitch, 1997; Taylor and Todd, 1995; Szajna, 1996; Venkatesh and Davis, 2000) or simply identifying relevant factors in building trust per se (McKnight, Choudhury, et al. 2002, Gefen 2003) (Currall and Judge, 1995; Gefen et al., 2003; McKnight et al., 2002) to evaluate an explanatory power of determinant factors. Unlike previous attempts, this study presents an integrated, parsimonious model of transactional e-government web service adoption that incorporates constructs from TAM, trust belief, perceived risk, and further information privacy concerns.

Secondly, the study provides empirical or at least statistical evidence in the controversial argument of the relationship between trust and perceived risk. Some researchers such as Mayer et al. (1995) cast a doubt a causal relationship from trust to perceived risk even though literature offers the causality in this way, in which risk mediates the relationship between trust and behavior. The framework of the research was initially designed to follow this assertion. However, the statistical result leads the study to modify a causal relationship from perceived risk to trust belief, which is also claimed by Olson and Olson (2000). They purported the people tend to trust more when low risk is perceived. Hence, the current study suggests a clue for academia to revisit the relationship in many different circumstances.

\section{Table 4. Summary results of Hypothesis Tests}

\begin{tabular}{|l|c|c|c|}
\hline \multicolumn{1}{|c|}{ Statement of Hypothesis } & $\lambda$ & t-value & Test Result \\
\hline $\begin{array}{l}\text { H1: Citizens intentions to transact online with e-Government are positively } \\
\text { related to trust beliefs in e-Government. }\end{array}$ & $0.331^{* *}$ & 4.300 & Supported \\
\hline $\begin{array}{l}\text { H2: Citizen intentions to transact with e-Government are negatively related to } \\
\text { risk perceptions in e-Government. }\end{array}$ & -0.024 & -0.429 & Not supported \\
\hline $\begin{array}{l}\text { H3: Risk beliefs in e-Government are negatively related to trust beliefs in e- } \\
\text { Government. }\end{array}$ & $-0.130^{*}$ & -1.765 & Supported \\
\hline $\begin{array}{l}\text { H4: Citizen intentions to transact with e-Government are positively related to } \\
\text { the perceived ease of use of e-Government. }\end{array}$ & 0.122 & 1.600 & Not supported \\
\hline $\begin{array}{l}\text { H5: Citizen intentions to transact with e-Government are positively related to } \\
\text { the perceived usefulness of e-Government. }\end{array}$ & $0.257^{* *}$ & 3.644 & Supported \\
\hline $\begin{array}{l}\text { H6: The perceived usefulness of e-Government is positively related to the } \\
\text { perceived ease of use of e-Government. }\end{array}$ & $0.439^{* *}$ & 6.094 & Supported \\
\hline $\begin{array}{l}\text { H7: Trust beliefs in e-Government are positively related to the perceived ease } \\
\text { of use of e-Government. }\end{array}$ & $0.319^{* *}$ & 4.646 & Supported \\
\hline $\begin{array}{l}\text { H8: Trust beliefs in e-Government are positively related to the perceived } \\
\text { usefulness of e-Government. }\end{array}$ & $0.196^{* *}$ & 2.802 & Supported \\
\hline $\begin{array}{l}\text { H9: Citizens' information privacy concerns are positively related to risk } \\
\text { beliefs in e-Government. }\end{array}$ & $0.757^{* *}$ & 7.478 & Supported \\
\hline $\begin{array}{l}\text { H10: Citizens' information privacy concerns are negatively related to trusting } \\
\text { beliefs in e-Government. }\end{array}$ & 0.011 & 0.159 & Not supported \\
\hline$*$ p < $0.10 * *$ p < 0.05 & & \\
\hline
\end{tabular}


Finally, this study confirms the claim from the revised TAM that differentiates the post-implementation version from the pre-implementation version that we are well aware of. Davis, Bagozzi, and Warshaw (1989) maintained and empirically supported the plausibility of this postimplementation TAM that, after having experience with IS, people found the ease of use affected on usefulness rather on usage intention directly. This research also found indirect relationships between perceived ease of use and behavioral intention since the respondents were exposed to some information finding task before answer the questionnaire. This post-experience acceptance has been rarely explored but maybe a more crucial research topic to academia and give a greater implication to industry.

For practical contribution, the study posits what would be possible barriers to e-government adoption. Today information technologies are heavily applied not only in the private sector but also vigorously to government units at national, regional, and local levels around the world. As introduced earlier, however, the large portion of citizens, allegedly from one-half to two-thirds of the adult population remains outside of the world of digital government. It poses a serious systematic constraint to technology's ability to transform citizens' behavior and attitude. In this sense, this study provides empirical evidence in the context of TAM where the easiness of using and browsing e-government web site will directly affect citizens' perception of the usefulness of transactional e-government web services and subsequently leads to usage intention. Hence from an administrative point of view, there is a great need to employ measures for enhancing users' easiness of using the services. For instance, providing online tutorials, 24-7 help desk, and prompt feedback are one of the ways for citizens to quickly and effortlessly find relevant information and carry out tasks easily.

Second of all, the research also found that it is imperative to increase trustability as e-governments are implementing more personalized and tailored web-based services comparable to the one in e-commerce. Trust belief may be the most challenging yet vital factor for government agencies to increase to facilitate especially the adoption of transactional e-government services. As suggested in the present study, to increase trust belief, it may require egovernment websites to reduce citizen users' privacy concerns by specifying noticeable privacy statements on their websites. In doing so, e-government services will progress to maturity in e-government evolution, the realization of e-democracy.

\section{References}

Accenture (2004) E-government leadership: High performance, maximum value. Retrieved September 10, 2005 from http://www.accenture.com/xdoc/en/industries/government/gove_egov_value.pdf

Ajzen, I. (1991) The theory of planned behavior, Organizational Behavior and Human Decision Processes, 50, 2, $179-211$.

Ajzen, I., and Fishbein, M. (1980) Understanding Attitudes and Predicting Social Behavior, Prentice-Hall, Englewood Cliffs, NJ.

Al-Hujran, O. Aloudat, A. and Altarawneth, I. (2013) Factors influencing citizen adoption of e-government in developing countries: The case of Jordan. International Journal of Technology and Human Interaction, 9(2), 1-19.

Bansal, G., Zahedi, F. and Gefen, D. (2010) The impact of personal dispositions on information sensitivity, privacy concern and trust in disclosing health information online, Decision Support Systems, 49(2), 138-150.

Belanche, D.M Casalo, L.V., Flavian, C., and Schepers, J. (2014) Trust transfer in the continued usage of public e-services, Information and Management, 51(6), 627-640.

Belanger, F. and Carter, L. (2008) Trust and risk in e-government adoption, The Journal of Strategic Information Systems, 17(2), 165-176.

Benassi, P. (1999) Trustee: An online privacy seal program, Communications of the ACM, 42(2), 56-59.

Bensaou, M. and Venkatraman, N. (1996) Inter-organizational relationships and information technology: A conceptual synthesis and a research framework, European Journal of Information Systems, 5, 2, 84-91.

Bonham, G., Seifert, J., \& Thorson, S. (2001). The transformational potential of e-government: The role of political leadership. presented at the 4th Pan European International Relations Conference, 6-10 September 2001, Canterbury, AU.

Brunschwig, C. R. (2006). Visualizing legal information: Mind maps and e-government. Electronic Government, an International Journal, 3(4), 386-403.

Campbell, A. (1999) Relationship marketing in consumer markets: A comparison of managerial and consumer attitudes about information privacy, Journal of Direct Marketing, 11(3), 44-57.

Carter, L. and Belanger, F. (2005) The utilization of e-government services: citizen trust, innovation and acceptance factors, Information Systems Journal, 15(1), 5-25. 
Cater, L., Weerakkody, V., Phillips, B., and Dwivedi, Y.K. (2016) Citizen adoption of e-government services: Exploring citizen perceptions of online services in the United States and United Kingdom. Information Systems Management, 33(2), 124-140.

Casalo, L.V., Flavian, C. and Guinaliu, M. (2007) The role of security, privacy, usability and reputation in the development of online banking, Online Information Review, 31(5), 583-603.

Chen, J.V., Jubilado, R.J.M., Capistrano, E.P.S. and Yen, D.C. (2015) Factors affecting online tax filing-an application of the IS success model and trust theory, Computers in Human Behavior, 43, 251-262.

Chircu, A., Davis, G. and Kauffman, R. (2000) Trust, expertise and e-commerce intermediary adoption, Proceedings of the Sixth Americas. Conference on Information Systems, ACM, New York, NY, 710-716.

Chiu, C., Chang, C., Cheng, H. and Fang, Y. (2009) determinants of customer repurchase intention in online shopping, Online Information Review, 33(4), 761-784.

Corbitt, B., Thanasankit, T. and Yi, H. (2003) Trust and e-commerce: a study of consumer perceptions, Electronic Commerce Research \& Applications, 2(3), 203-216.

Culnan, M. (1993) How did you get my name? An exploratory investigation of consumer attitudes toward secondary information use, MIS Quarterly, 17(3), 341-363.

Culnan, M. and Williams, C. (2009) How ethics can enhance organizational privacy: Lessons from the Choice Point and TJX data breaches. MIS Quarterly, 33(4), 673-687.

Davis, F. D. (1986) A Technology Acceptance Model for Empirically Testing New End-User Information Systems: Theory and result, Unpublished Doctoral Dissertation, MIT, Cambridge, MA.

Davis, F. (1989) Perceived usefulness, perceived ease of use, and user acceptance of information technology, MIS Quarterly, 13(3), 319-340.

Davis, F. D., Bagozzi, R. P., \& Warshaw, P. R. (1989) User acceptance of computer technology: A comparison of two theoretical models, Management Science, 35(8), 982-1003.

Dinev, T., and Hart, P. (2006) An extended privacy calculus model for e-commerce transactions, Information Systems Research, 17(1), 61-80.

Fishbein, M. and Ajzen I. (1975) Belief, Attitude, Intention and Behavior: An Introduction to Theory and Research, Addison-Wesley, MA.

Fountain, J. (2001) The virtual state: Transforming American government? National Civic Review, 90(3), 241-251.

Fukuyama, F. (1995) Trust: The social virtues and the creation of prosperity, Free Press, New York.

GAO (General Accounting Office), McClure, D. (2001) Electronic government: challenges must be addressed with effective leadership and management, General Accounting Office, Retrieved September 10, 2005, from http://www.gao.gov/new.items/d01959t.pdf.

Gefen, D. (2002). Nurturing clients' trust to encourage engagement success during the customization of ERP systems. Omega, 30(4), 287-299.

Gefen, D., Karahanna, E. \& Straub, D. (2003) Trust and TAM in online shopping: An integrated model, MIS Quarterly, 27(1), 51-90.

Gefen, D. and Keil, M. (1998) The impact of developer responsiveness on perceptions of usefulness and ease of use: An extension of the technology acceptance model, The DATA BASE for Advances in Information Systems, 29(2), 3549.

Gefen, D., Rao, V. S. and Tractinsky, N. (2003) The conceptualization of trust, risk, and their relationship in electronic commerce: The need for clarifications, Proceedings of the 36th Hawaii International Conference on system Science, January 6-9, Big Island, Hawaii, USA.

Gefen D. \& Straub, D. (2003) Managing user trust in B2C e-Services, e-Service Journal, 2(2), 7-24.

Gefen, D. and Straub, D. (1997) Gender differences in the perception and use of e-mail: An extension to the technology acceptance model, MIS Quarterly, 21(4), 389-400.

Gilbert, D. and Balestrini, P. (2004) Barriers and benefits in the adoption of e-government, The International Journal of Public Sector Management, 17(4), 286-301. 
Gilliland, S. (1993) The perceived fairness of selection systems: An organizational justice perspective, Academy of Management Review, 18(4), 694-734.

Glazer, R. (1991) Marketing in an information-intensive environment: Strategic implications of knowledge as an asset, Journal of Marketing, 55(4), 1-19.

Gore, A. (1993) From Red Tape to Results: Creating a Government That Works better and Costs Less, Times Books, New York.

Green, H. (2001, April 23) News: Analysis \&commentary: Your right to privacy: going . . going . Business Week Online, Retrieved September 10, 2005, from http://www.businessweek.com.

Hagel III, J. and Rayport, J. (1997) The coming battle for consumer information, Harvard Business Review, 53-65.

Hart-Teeter (2003, April). The new e-government equation: ease, engagement, privacy and protection. Retrieved September 10, 2009, from http://www.excelgov.org.

Henderson, S. \& Snyder, C. (1999) Personal information privacy: implications for MIS managers, Information and Management, 36(4), 213-220.

Hu, L. \& Bentler, P. M. (1999) Cutoff criteria for fit indexes in covariance structure analysis: Conventional criteria versus new alternatives, Structural Equation Model, 6(1), 1-55.

Jarvenpaa, S. and Tractinsky, N. (1999) Consumer trust in an Internet store: A cross-cultural validation, Journal of Computer Mediated Communication, 5(2), 1-35.

Jarvenpaa, S., Tractinsky, N. and Vitale, M. (2000) Consumer trust in an Internet store, Information Technology and Management, 1(12), 45-71.

Konovsky, M. and Pugh, S. (1994) Citizenship behavior and social exchange, Academy of Management Journal, 37(3), 656-669.

Lederer, A., Maupin, D., Sena, M. and Zhuang, Y. (1999) The technology acceptance model and the World Wide Web, Decision Support Systems, 29(3), 269-282.

Lian, J.W. (2015) Critical factors for cloud-based e-invoice service adoption in Taiwan: An empirical study, International Journal of Information Management, 35(1) 98-109.

Lips, A.M., Gil-Garcia, J.R. and Sorrentino, M. (2012). Introduction to the transformational government minitrack. 2013 46th Hawaii international conference on systems sciences, vol. 12592.

Liu, C., Marchewka, J., Lu, J. and Yu, C. (2004) Beyond Concern: A Privacy-Trust-Behavioral Intention Model of Electronic Commerce, Information and Management, 42(1), 127-140.

Lou, X. (2002) Trust production and privacy concerns on the Internet: A framework based on relationship marketing and social exchange theory, Industrial Marketing Management, 31(2), 111-118.

Malhotra, N., Kim, S. and Agarwal, J. (2004) Internet users' information privacy concerns (IUIPC): The construct, the scale, and a causal model, Information Systems Research, 15(4), 336-355.

Marchionini, G., Samet, H. and Brandt, L. (2003) Digital government, Communications of the ACM, 46(1), 25-27.

Mayer, R. C. and Davis, J. H. (1999) The effect of the performance appraisal system on trust in management: A field quasi-experiment, Journal of Applied Psychology, 84(1), 123-136.

Mayer, R. C., Davis, J. H. and Schoorman, F. D. (1995) An integrative model of organization trust, Academy of Management Review, 20(3), 709-734.

McKnight, D. H., Choudhury, V. and Kacmar, C. (2002) Developing and validating trust measures for e-commerce: An integrative typology, Information Systems Research, 13(3), 334-359.

McKnight, D. H., Cummings, L. L. and Chervany, N. L. (1998) Initial trust formation in new organizational relationships, The Academy of Management Review, 23(3), 473-490.

Milberg, S., Burke, S., Smith H. and Kallman, E. (1995) Values, personal information privacy, and regulatory approaches, Communications of the ACM, 38(12), 65-84.

Moon, J. and Kim, Y. (2001) Extending the TAM for a World-Wide-Web context, Information and Management, $38(4), 217-230$. 
Olivero, N. \& Lunt, P. (2004) Privacy versus willingness to disclose in e-commerce exchanges: The effect of risk awareness on the relative role of trust and control, Journal of Economic Psychology, 25, 243-262.

Olson, G.M. \& Olson, J.S. (2000) Distance Matters, Human-Computer Interaction, 15, 139-178.

Ozkan, S. and Kanat, I.E. (2011) E-government adoption model based on theory of planned behavior: Empirical validation. Government Information Quarterly, 28(4), 503-513.

Pantagiotopoulos, P., Al-Dehei, M.M., Fizgerald, G. and Elliman, T. (2012). A business model perspective for ICTs in public engagement, Government Information quarterly, 29(2), 192-202.

Pavlou, A. (2003) Consumer Acceptance of Electronic Commerce: Integrating Trust and Risk with the Technology Acceptance Model, International Journal of Electronic Commerce, 7(3), 69-103.

Rana, N.P., and Dwivedi, Y.K. (2015) Citizen's adoption of an e-government system: Validating extended social cognitive theory (SCT). Government Information Quarterly, 32(2), 172-181.

Reddic, C.G., and Roy, J. (2013). Business perceptions and satisfaction with e-government: Findings from a Canadian Survey, Government Information Quarterly, 30(1), 1-9.

Reichheld, F. and Schefter, P. (2000) E-loyalty: your secret weapon on the web, Harvard Business Review, 78(4), 105-113.

Ring, P. \& Van de Ven, A. (1994) Developing Processes of Cooperative Inter-Organizational Relationships,

Academy of Management Review, 19(1), 90-118.

Rodrigues, G., Sarabdeen, J., and Balasubramanian, S. (2016) Factors that influence consumer adoption of e-government services in the UAE: A UTAUT model perspective, Journal of Internet Commerce, 15(1) 18-39.

Rose, J., Persson, J., Heeager, L. and Irani, Z. (2015). Managing e-Government: value positions and relationships, Information Systems Journal, 25, 531-571.

Roy, M.C., Chartier, A., Crete, J. and Poulin, D. (2015) Factor influencing e-government use in non-urban areas, Electronic Commerce Research, 15(3), 349-363.

Salam, A., Lakshmi, I., Palvia, P. and Singh, R. (2005) Trust in E-Commerce, Communications of the ACM, 48(2), 73-77.

Siau, K. \& Shen, Z. (2003) Building Customer Trust in Mobile Commerce, Communications of the ACM, 46(4), 91-94.

Siau, K., Sheng, H., Nah, F. \& Davis, S. (2004) A qualitative investigation on consumer trust in mobile commerce, International Journal of Electronic Business, 2(3), 283-300.

Sirdeshmukh, D., Singh, J. and Sabol, B. (2002) Consumer Trust, Value, and Loyalty in Relational Exchanges, Journal of Marketing, 66(1), 15-37.

Smith, H., Dinev, T. and Xu, H. (2011) Information Privacy Research: An Interdisciplinary Review, MIS Quarterly, 35(4), 989-1015.

Smith, H., Milberg, S. and Burke, S. (1996) Information Privacy: Measuring Individuals' Concerns about Corporate Practices, MIS Quarterly, 20(2), 167-196.

Stepanek, M. (1999, July) Protecting E-privacy: Washington must Step in, Business Week, EB30.

Stewart, K. and Segars, A. (2002) An Empirical Examination of the Concern for Information Privacy Instrument, Information Systems Research, 13(1), 36-49.

Suh, B. \& Han, I. (2003) The Impact of Customer Trust and Perception of Security Control on the Acceptance of Electronic Commerce, International Journal of Electronic Commerce, Spring2003, 7(3), 135-161.

Szajna, B. (1996) Empirical Evaluation of the Revised Technology Acceptance Model, Management Science, 42(1), 85-92.

Taylor Nelson Sofres (2002) Government Online Study. Retrieved from http://unpan1.un.org/intradoc/groups/public/documents/APCITY/UNPAN007044.pdf.

Taylor, S. and Todd, P. (1995a) Assessing IT Usage: The Role of Prior Experience, MIS Quarterly, 19(4), 561-570.

Taylor, S. and Todd, P. (1995b) Understanding Information Technology Usage: A Test of Competing Models, Information Systems Research, 6(2), 144-176.

Thibault, J. and Kelley, H. (1959) The Social Psychology of Groups, John Wiley \& Sons, New York, NY. 
UN e-government survey (2018) Gearing e-government to support transformation towards sustainable and resilient societies. Retrieved from https://publicadministration.un.org/egovkb/Portals/egovkb/Documents/un/2018-Survey/EGovernment\%20Survey\%202018_FINAL\%20for\%20web.pdf

Venkatesh, V. and Davis, F. D. (2000) A Theoretical Extension of the Technology Acceptance Model: Four Longitudinal Field Studies, Management Science, 46(2), 186-204.

Wang, Y. (2003) The adoption of electronic tax filing systems: an empirical study, Government Information Quarterly, 20(4), 333-352.

Wang, W. and Benbasat, I. (2005) Trust in and Adoption of Online Recommendation Agents, Journal of the Association for Information Systems, 6(3), 72-101.

Warkentin, M., David G., Paul A. and Gregory M. (2002) Encouraging Citizen Adoption of E-Government by Building Trust, Electronic Markets, 12(3), 157-162.

Westin, A. F. (1967) Privacy and Freedom, Atheneum, New York, NY.

Xie, Q., Song, W, and Peng, X. (2017) Predictors for e-government adoption: Integrating TAM, TPB, trust and perceived risk, The Electronic Library, 35(1), 2-20.

Yu, J., Ha, I., Choi, M. and Rho, J. (2005) Extending the TAM for a t-commerce, Information \& Management, 42(7), 965-976. 